\title{
EFFECT OF CHLORPYRIFOS ON LIVER FUNCTION OF ALBINO RATES
}

\author{
Y. Ashoush ${ }^{(1)}$, M. Abozid ${ }^{(1)}$, S. Mansour ${ }^{(1)}$ and A. Morgan ${ }^{(2)}$ \\ (1) Biochemistry department, Faculty of Agriculture, Menoufia University. \\ (2) Central public health laboratories, Ministry of Health, Egypt.
}

Received: Feb. 9 , 2020

Accepted: Feb. 18,2020

\begin{abstract}
This study was conducted with the aim of studying the survival of chlorpyrifos on cucumber fruits. The fruits were applied by the recommended doses of chlorpyrifos. Residues of pesticides in fruits were determined used liquid chromatography.

The results showed that the residual chlorpyrifos decreased gradually due to time factor and the process of the fruit washing with water had a clear effect in reducing the concentration of the presence of chlorpyrifos in the applied fruits.

Chronic toxicity of chlorpyrifos on liver function after the pesticide application showed that pesticides induced some effects on different biological functions of experimental animals applied with pesticide.
\end{abstract}

Key words: Chlorpyrifos - liver function - cucumber - pesticides residues.

\section{INTRODUCTION}

Pesticides are one of the few toxic substances released deliberately into the environment to kill living organisms e.g., weeds (herbicides), insects (insecticides), fungus (fungicides), and rodents (rodenticides). Although the term pesticide is often misunderstood to refer only to insecticides, it is also applicable to herbicides, fungicides, and various other substances used to control pests' (Matthews, 2006). Agriculture is the largest consumer (around $85 \%$ of world production) of pesticides to chemically control various pests. Moreover, pesticides are also used in public health activities to control vector-borne diseases (e.g., malaria and dengue) and unwanted plants (e.g., grass and weeds) in ornamental landscaping, parks, and gardens. They are also useful in suppressing or avoiding the proliferation of insects, pests, bacteria, fungi, and algae in electrical equipment, refrigerators, paint, carpets, paper, cardboard, and food packaging materials (Gilden et al., 2010). However, unintended exposure to pesticides can be extremely hazardous to humans and other living organisms as they are designed to be poisonous (Sarwar, 2015). They may also be harmful to people who are exposed to pesticides through occupational (or home) use, eating foods or liquids containing pesticide residue, or inhalation (or contact) of pesticidecontaminated air (Pimentel et al., 2013). The physical makeup, behavior, and physiology of children make them more susceptible to pesticides than adults (Mascarelli, 2013). Pesticide exposure is linked with various diseases including cancer, hormone disruption, asthma, allergies, and hypersensitivity (Van Maele-Fabry et al., 2010). A line of evidence also exists for the negative impacts of pesticide exposure leading to birth defects, reduced birth weight, fetal death, etc. (Baldi et al., 2010 and Meenakshi et al., 2012 and Wickerham et al., 2012). In people, short-run oral exposure (one day) to low (milligrams) levels of organophosphate will cause a symptom, fatigue, runny nose or eyes, salivation, nausea, intestinal discomfort, 
sweating, and changes in heart rate. Short-term oral exposure to abundant higher (grams) levels of organophosphate might cause dysfunction, seizures, loss of consciousness, and death. Reports in folks conjointly show that short-run exposure to organophosphate might cause muscle weakness weeks once the first symptoms have disappeared. Other effects of exposure to organophosphate embrace changes in behavior or sleeping pattern, mood changes, and effects on the nerves and/or muscles in the limbs which may appear as odd sensations such as numbness or tingling or as muscle weakness (Solati et al., 2012).

\section{MATERIALS AND METHODS.}

\section{Materials}

\section{Chlorpyrifos}

Product name: pyrifos $48 \%$ EC Family: organophosphorous.

\section{Pesticides application.}

Cucumber fruits were planted in farm in Wardan Village in Giza governorate, Egypt. These plants were sprayed with recommended doses for chlorpyrifos according to the ministry of agriculture recommendation 2016.

\section{Kits.}

ALT, AST and ALP kits that used in analysis purchased by Spain React Company from Spain.

\section{Collection of plant fruits samples.}

Samples from cucumber was taken at random one hour and then after 1, 3, 7 and 14 days after the pesticides spraying.

The effect of washing process with water to eliminate pesticide residues from cucumber and, which was taken one hour and one day after the application, was studies.

\section{Methods.}

\section{Extraction and clean up.}

The technique extraction is QUECHERS method (AOAC, 2007).

- Ten g. of the sample were added to ten $\mathrm{ml}$ of acetonitrile then Shake for one min. Then mixture powder of $4 \mathrm{~g}$. MgSO4 + $1 \mathrm{gm}$ sodium citrate dehydrate +0.5 g. sodium sesquhydrate was added to the vortex for one min. Then the mixture centrifuged for $5 \mathrm{~min}$ at $4000 \mathrm{xg}$ then 6 $\mathrm{ml}$ from upper layer were transferred and put in dispersive tube which contain $150 \mathrm{mg}$ primary secondary amine (PSA) + $900 \mathrm{~g} \mathrm{MgSO4.} \mathrm{Then}$ vortexed 30 seconds. The mixture was centrifuged for $5 \mathrm{~min}$ at $4000 \mathrm{xg}$ after purification $1 \mathrm{ml}$ in vial was taken to inject.

\section{Determination.}

Chlorpyrifos determind by using Sciex 5500 Qtrap liquid chromatography equipped with triple mass spectrometer detector (MSD).

\section{Toxicological experiments.}

Animals of this investigation were a total of $\mathbf{5 0}$ healthy and sexually mature albino rats and concentrations of chlorpyrifos were 5.769 ppm, 3.436 ppm, $1.896 \mathrm{ppm}$ and $1.588 \mathrm{ppm}$.

\section{Chronic toxicity (4- months).}

Randomized groups of rats housed in cages were allocated into 5 intoxicated groups, each having 10 male rats, and induced by chlorpyrifos that determined on fruits after an hour of the pesticide application and after a day and after washing those fruits at the same times of the application through drinking water for 4 successive months . 
5. Biochemical analysis (Determination of liver functions in plasma).

Aspartate aminotransferase (AST) was determined according to the method of Murray (1984)a. and alanine aminotransferase (ALT) activities in plasma was determined according to the method of Murray (1984)b. While, alkaline phosphatase (ALP) activity in plasma was determined according to the method of Wenger (1984).

\section{Statistical analysis procedures.}

All data were subject to statistical analysis by one-way ANOVA test using SPSS software for windows version 22.

\section{RESULT AND DISCUSSION}

\section{Results.}

\section{Persistence of tested insecticides residues.}

Residues of chlorpyrifos of cucumber fruits at different intervals from insecticides application were shown in Table (1). The data showed that the concentrations of the initial deposits were $5.769 \mathrm{ppm}$ after one hour from application. These amounts were rapidly declined to $3.436 \mathrm{ppm}$ after one day from application. These residues were dissipated to different degrees with the time elapsed after 3, 7 and 14 days after insecticides application to reach 1.248 ppm, $0.051 \mathrm{ppm}$ and $0.019 \mathrm{ppm}$ for chlorpyrifos.

The data indicated that the loss of the residues was found to be continued on prolonging the time, where the percent loss rate amounted to $40.44,78.36,99.11$ and $99.67 \%$ for chlorpyrifos after 1, 3, 7 and 14 days after insecticides application, respectively.

\section{Removal of tested insecticides residues from cucumber fruits by washing process.}

The results in Table (2) showed levels at ppm and the percent of removal of each tested insecticide after treatment by washing process after one hour and one day of pesticide application. These results showed that chlorpyrifos residues on and in cucumber fruits were 5.769 . These amounts were reduced to 4.257 by washing process. With corresponding percent or removal was $\mathbf{2 6 . 2 0} \%$ after one hour of application.

The residues were 3.436 for chlorpyrifos after one day of pesticide application. These amounts were reduced to 2.962 after washing with tap water with corresponding percent of $48.65 \%$ removal rate.

Table (1): Residues and percentage rates of loss of chlorpiryfos in cucumber fruits.

\begin{tabular}{lcccccc}
\hline \multirow{2}{*}{ Pesticides } & \multicolumn{5}{c}{ Time after application ( days ) } \\
\cline { 3 - 7 } Chlorpiryfos & $\begin{array}{c}\text { Initial }^{* *} \\
\text { Residue }^{*}\end{array}$ & 5.769 & 3.436 & 1.248 & 0.051 & 0.019 \\
& $(\mathrm{ppm})$ & & & & & \\
& $\%$ loss & 00 & 40.44 & 78.36 & 99.11 & 99.67 \\
\hline
\end{tabular}

Values represent means obtained from 3 samples.

Initial: samples were taken one hour after pesticide application. 
Table (2): Effect of washing process on residues and percentage rates of loss of chlorpiryfos in cucumber fruits.

\begin{tabular}{lccccc}
\hline \multirow{2}{*}{ Pesticides } & \multicolumn{4}{c}{ Time after application (days ) } \\
\cline { 3 - 6 } Chlorpiryfos & $\begin{array}{c}\text { Initial }^{\star *} \\
\text { Residue } \\
\text { (ppm) }\end{array}$ & 5.769 & $\begin{array}{c}\text { After } \\
\text { washing }\end{array}$ & 1 & $\begin{array}{c}\text { After } \\
\text { washing }\end{array}$ \\
& \% loss & 00 & 26.257 & 3.436 & 2.962 \\
\hline
\end{tabular}

Values represent means obtained 3 samples.

Initial: samples were taken one hour after pesticide application.

All of present results confirm and agree the data Abou-Arab (1999), Ismail, et al., (1993), Nabarawy, et al., (1992) and Soliman (2001) they reported that the effects of washing tap water for 5,10 and $20 \mathrm{~min}$. on pesticide residues in cabbage had effect in reducing some pesticides. Washing with $10 \%$ acetic acid solution for $20 \mathrm{~min}$. caused loss in chlorpyrifos, p,p-DDT, cypermethrin and chlorothalonil. They reported also that partial removal was effected by the washing.

Washing was found effective in dislodging the residues as it depends on a number of factors like location of residues, age of residues, water solubility, temperature and type of washing. In earlier studies also showed effects of these factors were observed in different vegetables by various researchers (Sarode and Lal, 1982 and Dikshit et al., 1986).

Washing with tap water, had an effect in reducing trichlorfon, dimethoate, dichlorvos, fenitrothion and chlorpyrifos (Zhang et al., 2007and Abou-Arab, 1999).

A gradual reduction was also observed when increasing the time at the same concentration (Radwan et al., 2005). It has been recommended that cucumber should be washed with tap water and/or detergent solutions carefully to decrease the intake of pesticide residues before raw eating (Kaushik et al., 2009).

\section{Biochemical evaluation harmful effects in male albino rats caused by chlorpyrifos on plasma liver functions.}

\subsection{Effect of chlorpyrifos on plasma aspartate aminotransferase (AST)}

From the results presented in Table (3) chlorpyrifos effect showed, that there were insignificant changes in the AST activity between the albino rats control group and the albino rats in the $1^{\text {st }}, 2^{\text {nd }}$, $3^{\text {rd }}$ and $4^{\text {th }}$ study group.

Inside $1^{\text {st }}, 2^{\text {nd }}$ and $3^{\text {rd }}$ month the AST was elevated in the male albino rats with significant changes between the male albino rats control group and in the male albino rats $1^{\text {st }}, 2^{\text {nd }}, 3^{\text {rd }}$, and $4^{\text {th }}$ study group, respectively.

Moreover, during the recovery period, the AST was reduced in the male albino rats with significant changes between the male albino rats control group and in the male albino rats $1^{\text {st }}, 2^{\text {nd }}, 3^{\text {rd }}$ and $4^{\text {th }}$ study group, respectively. 
Menoufia J. Agric. Biotechnology, Vol. 5 April (2020): 83 - 92

Table 3: Effect of chlorpyrifos on plasma aspartate amino transferase AST activity in albino rats.

\begin{tabular}{cccccc}
\hline Pesticides & \multicolumn{5}{c}{ Chlorpyrifos } \\
\hline AST & $\begin{array}{c}\text { Control } \\
\text { Group } \\
\text { Oppm }\end{array}$ & $\begin{array}{c}1^{\text {st }} \begin{array}{c}\text { Study } \\
\text { Group }\end{array} \\
5.769 p p m\end{array}$ & $\begin{array}{c}2^{\text {nd }} \text { Study } \\
\text { Group } \\
3.436 p p m\end{array}$ & $\begin{array}{c}3^{\text {rd }} \text { Study } \\
\text { Group } \\
1.896 p p m\end{array}$ & $\begin{array}{c}4^{\text {th }} \text { Study } \\
\text { Group } \\
1.588 p p m\end{array}$ \\
Initial & $46.29 \pm 1.61$ & $46.64 \pm 0.74$ & $47.06 \pm 0.77$ & $47.09 \pm 1.18$ & $47.28 \pm 1.03$ \\
$1^{\text {st }}$ month & $43.45 \pm 3.77$ & $* 38.90 \pm 1.01$ & $* 37.45 \pm 1.26$ & $* 36.40 \pm 2.74$ & $* * 35.39 \pm 1.32$ \\
$2^{\text {nd }}$ month & $63.17 \pm 1.73$ & $* * 74.44 \pm 3.82$ & $* * 73.16 \pm 2.15$ & $* * 73.52 \pm 1.85$ & $* * 80.23 \pm 2.16$ \\
$3^{\text {rd }}$ month & $82.06 \pm 3.36$ & $* * 101.4 \pm 4.84$ & $* * 94.64 \pm 1.07$ & $* * 93.37 \pm 1.81$ & $* * 91.33 \pm 2.19$ \\
$\begin{array}{c}\text { Recovery } \\
\text { period }\end{array}$ & $81.96 \pm 2.69$ & $* * 49.55 \pm 1.29$ & $* * 51.62 \pm 1.89$ & $* * 51.20 \pm 1.48$ & $* * 51.41 \pm 1.91$ \\
\hline
\end{tabular}

Values represent means \pm S.D obtained from 5 animals. Significant level: ${ }^{*} p \leq 0.05 ;{ }^{* *} p \leq 0.01$; compare with control.

\subsection{Effect of chlorpyrifos on plasma alanine aminotransferase (ALT).}

From the results presented in Table (4) chlorpyrifos effect showed that there were insignificant changes in the ALT activity between the albino rats control group and the $1^{\text {st }}, 2^{\text {nd }}, 3^{\text {rd }}$ and $4^{\text {th }}$ study group.

Within one-month ALT activity was elevated with significant changes between the albino rats in the control group and the albino rats in the $1^{\text {st }}$ and $3^{\text {rd }}$ study group. There were insignificant changes between the albino rats in the control group and the $2^{\text {nd }}$ and $4^{\text {th }}$ study group.

Within two month can observe that, the ALT activity was elevated with significant changes between the albino rats in the control group and the albino rats in the $1^{\text {st }}, 2^{\text {nd }}, 3^{\text {rd }}$ and $4^{\text {th }}$ study group.

Within three month can observe that ALT activity was elevated with significant changes between the male albino rats in the control group and the $1^{\text {st }}, 2^{\text {nd }}, 3^{\text {rd }}$ and $4^{\text {th }}$ study group.

Furthermore, during the recovery period the ALT activity was returned to the normal with significant changes between the male albino rats in the control group and the $1^{\text {st }}, 2^{\text {nd }}, 3^{\text {rd }}$ and $4^{\text {th }}$ group.

\subsection{Effect of chlorpyrifos on plasma alkaline phosphatase (ALP).}

The results presented in Table (5) chlorpyrifos effect showed, there were insignificant changes in ALP between control group and the $1^{\text {st }}, 2^{\text {nd }}$ and $4^{\text {th }}$ study group. Meanwhile observe that, a significant change in the ALP activity between the albino rats in the control group and the albino rats in the $3^{\text {rd }}$ study group.

Within one-month ALP activity was elevated with significant changes between the albino rats in the control group and the albino rats in the $1^{\text {st }}$, $2^{\text {nd }}$ and $3^{\text {rd }}$ study group. Except there was 
the insignificant change in the ALP activity between the albino rats in the control group and the albino rats in the $4^{\text {th }}$ study group.

Table 4: Effect of chlorpyrifos on plasma alanin amino transferase ALT activity in albino rats.

\begin{tabular}{|c|c|c|c|c|c|}
\hline Pesticides & & & Chlorpyrifos & & \\
\hline $\begin{array}{l}\text { ALT } \\
\text { U/L }\end{array}$ & $\begin{array}{l}\text { Control } \\
\text { Group } \\
\text { Oppm }\end{array}$ & $\begin{array}{l}1^{\text {st }} \text { Study } \\
\text { Group } \\
5.769 p p m\end{array}$ & $\begin{array}{l}2^{\text {nd }} \text { Study } \\
\text { Group } \\
3.436 \mathrm{ppm}\end{array}$ & $\begin{array}{l}3^{\text {rd }} \text { Study } \\
\text { Group } \\
1.896 \mathrm{ppm}\end{array}$ & $\begin{array}{l}4^{\text {th }} \text { Study } \\
\text { Group } \\
1.588 p p m\end{array}$ \\
\hline Initial & $38.03 \pm 0.82$ & $38.89 \pm 1.97$ & $38.32 \pm 1.29$ & $37.94 \pm 1.35$ & $38.33 \pm 0.95$ \\
\hline $1^{\text {st }}$ month & $26.31 \pm 0.76$ & ${ }^{\star *} 34.73 \pm 4.03$ & $32.40 \pm 6.33$ & *32.29 \pm 4.04 & $27.02 \pm 4.50$ \\
\hline $2^{\text {nd }}$ month & $47.35 \pm 1.16$ & ${ }^{\star *} 64.46 \pm 4.40$ & ${ }^{\star *} 64.93 \pm 4.02$ & ${ }^{\star *} 62.69 \pm 4.85$ & $\star \star 58.85 \pm 5.62$ \\
\hline $3^{\text {rd }}$ month & $52.29 \pm 1.32$ & **83.22 \pm 4.26 & ${ }^{\star \star} 80.96 \pm 5.48$ & $\star \star 85.0 \pm 7.02$ & $\star \star 78.38 \pm 5.98$ \\
\hline $\begin{array}{l}\text { Recovery } \\
\text { period }\end{array}$ & $45.26 \pm 1.98$ & $\star \star 49.57 \pm 1.34$ & $\star \star 50.66 \pm 2.10$ & **53.65 \pm 1.71 & ${ }^{\star *} 52.46 \pm 1.40$ \\
\hline
\end{tabular}

Values represent means \pm S.D obtained from 5 animals.

Significant level: * $p \leq 0.05 ;{ }^{* *} p \leq 0.01$; compare with control.

Table 5: Effect of chlorpyrifos on plasma alkaline phosphatese ALP activity in albino rats.

\begin{tabular}{|c|c|c|c|c|c|}
\hline Pesticides & & & Chlorpyrifos & & \\
\hline $\begin{array}{l}\text { ALP } \\
U / L\end{array}$ & $\begin{array}{l}\text { Control } \\
\text { Group } \\
\text { Oppm }\end{array}$ & $\begin{array}{l}1^{\text {st }} \text { Study } \\
\text { Group } \\
5.769 \mathrm{ppm}\end{array}$ & $\begin{array}{c}2^{\text {nd }} \text { Study } \\
\text { Group } \\
3.436 \mathrm{ppm}\end{array}$ & $\begin{array}{l}3^{\text {rd }} \text { Study } \\
\text { Group } \\
\text { 1.896ppm }\end{array}$ & $\begin{array}{l}4^{\text {th }} \text { Study } \\
\text { Group } \\
1.588 p p m\end{array}$ \\
\hline Initial & $86.98 \pm 1.53$ & $88.12 \pm 1.32$ & $87.12 \pm 0.85$ & ${ }^{\star} 89.28 \pm 0.85$ & $85.80 \pm 1.53$ \\
\hline $1^{\text {st }}$ month & $120.52 \pm 2.41$ & $* * 137.70 \pm 2.01$ & ${ }^{* *} 132.30 \pm 5.57$ & **139.93 \pm 5.98 & $126.09 \pm 5.2$ \\
\hline $2^{\text {nd }}$ month & $137.26 \pm 1.46$ & ${ }^{\star *} 155.10 \pm 1.94$ & ${ }^{\star *} 153.96 \pm 5.57$ & ** $153.90 \pm 5.69$ & **150.90 \pm 3.4 \\
\hline $3^{\text {rd }}$ month & $159.22 \pm 1.33$ & ${ }^{* *} 180.34 \pm 5.28$ & **179.56 \pm 7.57 & *172.83 \pm 8.46 & **173.65 \pm 6.8 \\
\hline $\begin{array}{l}\text { Recovery } \\
\text { period }\end{array}$ & $167.12 \pm 1.21$ & ${ }^{* *} 128.40 \pm 1.71$ & ${ }^{* *} 123.02 \pm 1.10$ & ${ }^{\star \star *} 109.09 \pm 1.17$ & **97.89 \pm 1.7 \\
\hline
\end{tabular}

Values represent means \pm S.D obtained from 5 animals. Significant level: ${ }^{*} p \leq 0.05 ;{ }^{* *} p \leq 0.01$; compare with control.

Inside $2^{\text {nd }}$ and $3^{\text {rd }}$ month, the ALP activity was elevated in the albino rats with significant changes between control group and the $1^{\text {st }}, 2^{\text {nd }} 3^{\text {rd }}$ and $4^{\text {th }}$ study group, respectively.

Furthermore, during the recovery period the ALP activity was returned to the normal in the in albino rats in the $1^{\text {st }}$, $2^{\text {nd }}, 3^{\text {rd }}$ study group and $4^{\text {th }}$ group with significant changes.

\section{Discussion.}

The pesticidal effect on the liver function of experimental animals various periods revealed significant changes in the liver functions prameters. The changes in biochemical parameters are 
important to indicate the susceptibility of organ system to pollutants. In an organism toxic substances (such as pesticides) brings about a kind of stress and an organism responds to that by developing necessary potential.

Chlorpyrifos, which is an organophosphate insecticide, gets inside the cytoplasm from cells as a lipophilic molecule and harms cellular molecules inside the cell (Uzun et al., 2010). Oxidative damage first starts with the production of reactive oxygen types and causes damage in macromolecules such as lipid, DNA and protein (Ambali et al., 2011). Free radicals that occur as a result of oxidative stress, especially DNA, protein and cell phospholipids have an ability to react with a great number of organic and inorganic compounds, mainly multiple unsaturated fat acids (Bagchi et al., 1995 and Lodovici et al., 1997).

Mansour et al., (2009) assessed the effects of chlorpyrifos in rat liver histopathologically and showed that chlorpyrifos increased lipid peroxidation; decreased plasma superoxide dismutase (SOD), glutathione-S-transferase and serum acetyl choline esterase activities, also caused histopathological changes such as hepatocyte degeneration, focal inflammatory cell infiltrations and diffuse Kupffer cell proliferation.

The study of Celik and Suzek (2008) revealed that chlorpyrifos-treatment caused an increase in the activities of ALP, AST and ALT in serum of male rats. The increase in these enzymes may be due to liver dysfunction and disturbance in the biosynthesis of these enzymes with alteration in the permeability of liver membrane takes place. Moreover, chlorpyrifos is mainly due to the leakage of these enzymes from the liver cytosol into the blood stream. Researchers reported that enzymatic activities of AST and ALT are sensitive serological liver toxicity (Messerah et al., 2010).

High elevation of the liver enzymes (AST, ALT, ALP) are in agreement with findings of many researchers on experimental animals exposed to several OP insecticides including chlorpyrifos(CPF) and dizbean (DIZ) (Mansour et al., 2009 and Mansour and Mossa 2010). Moreover, altered liver enzyme activities have been previously reported among pesticide workers exposed to an OP pesticide alone or in combination with other pesticides (Kalender et al., 2010).

\section{Conclusion}

In spite of applied chlorperifos according to the recommendations, the residues of the pesticide in the fruits caused a significant increase in liver function. While, washing process leads to a decrease in the presence of chlorpyrifos residues in the fruits, which helps to reduce the risks to the body.

\section{REFERENCES}

Abou-Arab, A. A. K. (1999). Behavior of pesticide in tomatoes during commercial and home preparation. Food Chem. 65: 509-514.

Ambali, F.S., J.O. Ayo and E. Kan (2011). Hemotoxicity induced by chronic chlorpyrifos exposure in wistar rats: mitigating effect of vitamin C. Vet. Med. Int. 63: 201-215

AOAC, Association of official analytical chemists (2007). Pesticide residues in food by acetonitrile extraction and partitioning with magnesium sulfate Int. 90: 485.

Bagchi, D., M. Bagchi and E.A. Hassoun (1995). In vitro and in vivo generation of reactive oxygen species, DNA damage and lactate dehydrogenase leakage by selected pest. Tox.104:129140. 
Baldi, I., A. Gruber, V. Rondeau, P. Lebailly, P. Brochard and C. Fabrigoule (2010). Neurobehavioral effects of long-term exposure to pesticides: results from the 4-year followup of the phytoner study. Occup. Environ. Med. 68 (2): 108-115.

Celik, I. and H. Suzek (2008). The hematological effects of methyl parathion in rats. J. Hazard. Mater. 153: 1117-1121.

Dikshit, A.K., S.K. Handa and S. Verma (1986). Residues of methamidophos and effect of washing and cooking in cauliflower, cabbage and Indian Colza. Indian J. Agric Sci. 56: 661- 675

Gilden, R.C., K. Huffling and B. Sattler (2010). Pesticides and health risks. J. Obstet. Gynecol. Neonatal. Nurs. 39 (1): 103-110.

Ismail, S. M. M., H. M. Ali and R. A. Habiba (1993). GC-ECD and GC MS analysis of profenofos residues and its biochemical effects in tomatoes and tomatoes produces. Journal of Agric. and Food Chem. 41: 610-615.

Kalender, S., F.G. Uzun, D. Durak, F. Demir and Y. Kalender (2010). Malathion-induced hepatotoxicity in rats: the effects of vitamins $C$ and $E$. Food Chem. Toxicol. 48: 633-638.

Kaushik, G., S. Satya and S. N. Naik (2009). Food processing a tool to pesticide residue dissipation - A review. Food Research Inter. 42: 2640.

Lodovici, M., C. Cassalini and C. Briani (1997). Oxidative liver DNA damage in rats treated with pesticide mixtures. Toxi.117:55-60.

Mansour, M. K., A. A. I. El-Kashaury, M. A. Rasheed and K. M. Koretem (2009). "Oxidative and Biochemical Alterations Induced by Profenofos Insecticide in Rats." Natu. and Sci. 7 (2):1-14.
Mansour, S.A. and A.H. Mossa (2010). Oxidative damage, biochemical and histopathological alterations in rats exposed to chlorpyrifos and the antioxidant role of zinc. Pesticide Biochem. Physiol., 96: 14-23.

Mascarelli, A. (2013). Growing up with pesticides. Science 341 (6074), 740 Nurs. 39 (1): 103-110.

Matthews, G.A. (2006). Pesticides: Health, Safety and the Environment. Blackwell Publishing, Oxford, UK.

Meenakshi, Sharon, P., M. Bhawana and S. Anita (2012). A short review on how pesticides affect human health. Int. J. Ayurvedic Herbal Medic. 5: 935-946.

Messerah, M., A. Boumendjel, A. Chouabia, F. Klibet, C. Abdennour, M.S. Boulakoud and A. El Feki (2010). Influence of thyroid dysfunction on liver lipid peroxidation and antioxidant status in experimental rats. Exp. Toxicol. Pathol. 62: 301-310.

Murray, R. (1984)a. Alanine aminotransferase. Kaplan A et al .Clin chem. The C.V. Mosby Co. Si louis. Tronto. Princeton: 1088-1090.

Murray, R. (1984)b. Aspartate aminotransferase. Kaplan A et al .Clin chem. The C.V. Mosby Co. Si louis. Tronto. Princeton: 1112-1116.

Nabarawy, I. M., M. A. Abou-Donia and H. A. Amra (1992). Determination of profenofos and malathion residues in fresh tomatoes and paste. Egypt. J. of Appl. Sci., 7: 106-111.

Pimentel, D., T.W. Culliney and T. Bashore (2013). Public Health Risks Associated with Pesticides and Natural Toxins in Foods. IPM World Textbook. Regents of the University of Minnesota.

Radwan, M. A., M. M. Abu-Elamayem, M. H. Shiboob and A. Abdel-Aal (2005). Residual behaviour of profenofos on some field-grown vegetables and its removal using various washing 
solutions and household processing. Food Chem. Toxi. 43: 553-557.

Sarode, S.V. and R. Lal (1982). Dissipation of fenitrothion residues on cauliflower. Indian J. Agric Sci. 56: 173-176.

Sarwar, M. (2015). The dangers of pesticides associated with public health and preventing of the risks. Int. J. Bioinfor. Biomed. Eng. 1 (2): 130136.

Solati, A., A. Tavasoly, M.K. Koohi, S.H. Marjanmehr and B. Rezvanjoo (2012). Effects of dermal exposure to chlorpyrifos on liver and brain structures and biochemical parameters in rabbits. Comp. Clin. Pathol. 21: 1211-17.

Soliman, K. M. (2001). Changes in concentration of pesticide residue in potatoes during washing and home preparation. Food Chem. Toxi. 39; 887-891.
Uzun, F.G., F. Demir and S. Kalender (2010). Protective effect of catechin and quercetin on chlorpyrifos-induced lung toxicity in male rats. Food Chem. Toxi.48:1714-1720.

Van Maele-Fabry, G., A.C. Lantin, P. Hoet and D. Lison (2011). Residential exposure to pesticides and childhood leukaemia: a systematic review and meta-analysis. Environ. Int. 37 (1): 280-291.

Wenger, C. (1984). Alkaline phosphatase. Kaplan A et al. Clin chem. The C.V. Mosby Co. Si louis. Tronto. Princeton: 1094-1098.

Wickerham, E.L., B. Lozoff, J. Shao, N. Kaciroti, Y. Xia and J.D. Meeker (2012). Reduced birth weight in relation to pesticide mixtures detected in cord blood of full-term infants. Environ. Int. 47: 80-85.

Zhang, Z. Y., X. J. Liu and X. Y. Hong (2007). Effects of home preparation on pesticide residues in cabbage. Food Control, 18: 1484-1487. 
تأثير مبيد الكلوربيريفوس علي وظائف كبا الجرزان البيضاء

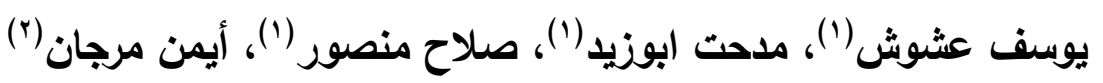

(1) قسم الكيمياء الحيوية - كلية الزراعة - جامعة المنوفية .

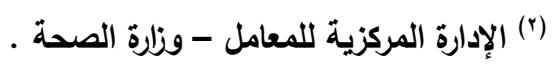

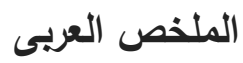

اجريت هذه الاراسة بهاف دراسة بقاء مبيد الكلوربيريفوس على محصول الخيار ودراسة سمية المبيد علي وظائف

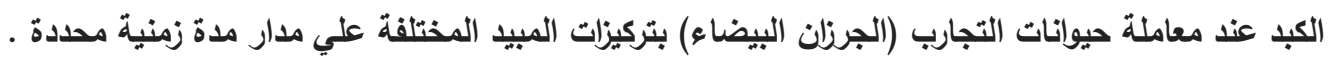

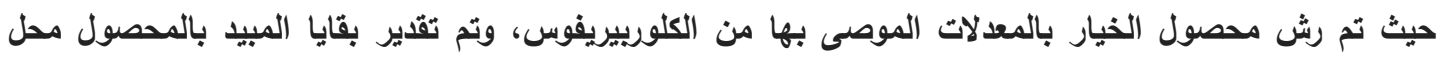
الاراسة الخيار باستخدام الكروماتوجرافي السائل .

ويدراسة تأثير عاملي الوقت والغسيل علي بقاء المبيد في المحصول تبين أن عامل الوقت يؤثثر علي بقاء المبيد حيث

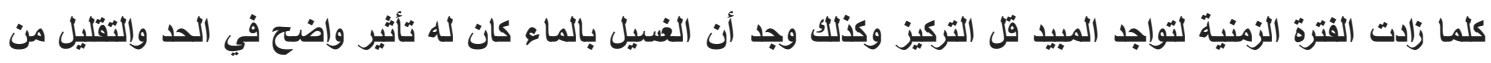
تركيز وجود الكلوربيريفوس في النبات. و أظهرت دراسة السمية المزمنة للكلوربيريفوس تأثيرا واضحا على وظائف الكبد وتبين أن المبيا يؤدي الي ارتفاع وظائف الكبا بثكل مرضي ويزيادات معنوية. 
السادة المحكمبن

أ.د/ إمام عبدالمبدئ عبدالرحيم كلية الزراعة - جامعة القاهرة

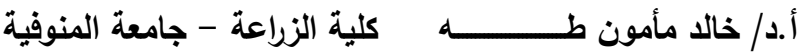



Menoufia J. Agric. Biotechnology, Vol. 5 April (2020): 83 - 92

ملخص عربي 
Menoufia J. Agric. Biotechnology, Vol. 5 April (2020): 83 - 92 